\title{
A Critical Review on Quality Testing of Milk and Milk Products
}

\author{
Harleen Kaur Talwar ${ }^{1 *}$ and Anshu Sibbal Chatli ${ }^{2}$ \\ ${ }^{1}$ Department of Biotechnology, ${ }^{2}$ Department of Microbiology, Guru Nanak Girls College, \\ Model Town, Ludhiana, Punjab, India \\ *Corresponding author
}

A B S T R A C T

\section{Ke y w o r ds \\ Milk, Milk products, Quality \\ Article Info \\ Accepted: \\ 10 July 2020 \\ Available Online: \\ 10 August 2020}

Nutritious and clean milk supply should be the main mission of every dairy producer. The quality of milk products starts at the farm and continues throughout processing. To meet increased raw milk quality standards, producers must adopt production practices that reduces bacterial contamination of milk. Use of effective management strategies to minimize contamination of raw milk will help dairy producers achieve these important goals.

\section{Introduction}

Milk is an imperative product of human diet which is essentially an emulsion of fat and protein in water, along with dissolved sugar. Raw farm milk and full fat milk have their own percentage of fat (Kala et al., 2018). Poor quality affects all the segments of dairy industry, ultimately resulting in milk with decreased manufacturing properties and dairy products with reduced shelf life. Milk has to be pasteurized as a protection against pathogenic organisms.

Pasteurization is a partial sterilization accomplished by raising the milk to a temperature high enough to destroy of the causing spoilage. Several different methods are used to assess milk quality such as the Somatic cell count (SCC) and Standard plate count (SPC). The Standard plate count is an estimate of the total number of aerobic bacteria present in raw milk. The test is done in 48 hours at $90^{\circ} \mathrm{F}$ followed by counting bacteria that grow on plates.

The SPC is used to moniter progress since consistence application of proper milking practices, under hygiene and good mastitis prevention and contol practices should allow diary producers to produce milk with low SPC, which is less than 5000 colony forming units (cfu) of bacteria per mL. Federal regulations defined in the pasteurised milk ordinance mandate that the milk SPC should not exceed $100,000 \mathrm{cfu} / \mathrm{mL}$. 


\section{Contamination in Raw Milk}

Mathur (1959) reported an outbreak of salmonellosis due to Salmonella weltevredon in a family associated with the consumption of contaminated raw milk. Murry (1966) conducted a survey to see the incidence of salmonellae in Northern Ireland milk supplies. None of the bulk collected samples contained Salmonella. He could isolate S. Dublin in the milk from two individual producers. A total of 205 pooled samples of raw buffalo milk collected at NDRI, Karnal were were analyzes for the presence of Salmonella by Singh and Singh (1966). They could isolate Salmonella from two samples. Garg et al (1977) isolated Salmonella from both, cow and buffalo milk. This organism was isolated from both samples on the same day indicating a possible common source of contamination which may either be milking utencils or the milker.

Taylor et al (1982) reported that an outbreak of salmonellosis occurred due to the consumption of raw milk. Galbraith et al (1982) reported that, 233 cases of outbreaks of communicable disease have occurred in England and Wales between 1951 and 1980 due to milk or dairy products that affected nearly 10000 people, of whom four died.

Milk-borne outbreaks of salmonellosis and campylobacter enteritis occurred due to raw or defectively pasteurised milk. They suggested that heat treatment of milk is an effective preventive measure. MMWR in 1984 reported Salmonella dublin infections from 1981-1983 due to the use of certified raw milk. Wood et al (1984) tested the samples from 18 farms, supplying milk to cheese factory, for the presence of Salmonella. Milk samples from one farm were found positive. Analysis of milk samples from a herd of 35 cows revealed only one cow shedding S.muenster directly into the milk. Eleven out of the 181 vats of cheese were found positive for Salmonellae at curd stage and only two at finished stage. The isolation of Salmonella from milk filters, cream and five farm workers in England and Wales. A total of 162 raw milk samples collected from open and closed cans in Calcutta city were examined by Das and Nag (1986). Five samples were positive for Salmonella.

McManus and Lanier (1987) analyzed 678 samples of raw milk from bulk tank trucks of milk suppliers in Wisconsin, Michigan and Illinois. Salmonellae were isolated from $32(4.7 \%)$ samples.

Humphrey and Hart (1988) isolated Campylobacters and salmonellae from 6 and $0.2 \%$ of samples of unpasteurized cow's milk on sale to the public. They also observed that there was a significant association between the presence of Escherichia coli and that of Campylobacter jejuni. The campylobacterpositive samples were having higher E.coli count indicating faecal contamination. Vasavada (1988) reported that pathogenic bacteria are transmissible to humans through milk and milk products. Milk, cheese, and ice cream are most commonly contaminated with pathogenic bacteria, viz., Listeria monocytogenes, Yersinia enterocolitica, Campylobacter jejuni, and enteropathogenic Escherichia coli. Adesiyun (1994) evaluated the bacteriological quality of pre-processed raw milk originating from all 16 milk collection centres in Trinidad. The mean total aerobic counts for bacteria, Staphylococcus aureus and E. coli were determined. The $\mathrm{pH}$ and presence of somatic cells in milk were also determined. Pre-processed milk in Trinidad was found to be of poor bacteriological quality showing the high counts of S. aureus in milk, which is of public health significance to consumers.

Ombui et al., (1994) investigated the rate of contamination with coliforms and incidence 
of E. coli in raw milk supplied by farmers to dairy cooperative societies. About 42.2\% percent of the milk samples from farmers cans and $10.3 \%$ of samples from cooperative cans were found to be free of coliforms, while $89.5 \%$ of the samples from farmers cans and $50 \%$ samples from cooperative cans could he considered to be of good quality with no more than 50,000 coliforms/ml of milk. Forty two E. coli strains were isolated from milk samples, five of which were found to be enteropathogenic, while none was found to be of serogroup 0157 . The results indicated that a good number of farmers draw milk under satisfactory conditions. Again the study showed that raw milk can get contaminated with enteropathogenic strains of $E$. coli that can pose a potential risk to humans, thus calling for extra care when preparing milk and milk products that are to be consumed by human beings.

Desmasures et al (1997) collected raw milk samples from 27 farms over 6 months for Listeria, Salmonella, Yersinia enterocolitica and Campylobacter. Total bacterial counts and somatic cell counts were measured. Lactococci, Lactobacilli, dextran-producing leuconostocs, Brevibacterium linens, yeasts and moulds, Staphylococcus aureus and other Micrococcaceae, Pseudomonas, coliforms, Escherichia coli, Enterococci, Clostridium perfringens and spores of anaerobic lactatefermenting bacteria were also counted. Pseudomonas (2000 cfu/ml), lactococci $(760$ $\mathrm{cfu} / \mathrm{ml})$ and Micrococcaceae $(720 \mathrm{cfu} / \mathrm{ml})$ were the most numerous groups. Lactic acid bacteria were detected in all samples. Coliforms were present in most samples, but $84 \%$ of samples had counts $<100 \mathrm{cfu} / \mathrm{ml}$. Staphylococcus aureus was detected in $62 \%$ of milks, the average count was $410 \mathrm{cfu} / \mathrm{ml}$. About $80 \%$ of supplies had $<$ or $=10 \mathrm{E}$. coli $\mathrm{cfu} / \mathrm{ml}$ and all samples had $<$ or $=1$ Cl.perfringens $\mathrm{cfu} / \mathrm{ml}$. Two of the tested milks were positive for Salmonellas (2.9\%), four were positive for Listeria monocytogenes (5.8\%), 25 for Yersinia enterocolitica (36\%) and one for campylobacters $(1.4 \%)$.

Matta and Punj (1999) examined 100 samples of raw milk, $48 \%$ were found to contain lipolytic, psychrotrophic, spore forming bacilli. On the basis of morphological and biochemical characteristics, the 59 lipolytic isolates were identified as Bacillus cereus, B.polymyxa, B.licheniformis, B.circulans, B. subtilis, B.laterosporus and B. coagulans. B. cereus $(32.2 \%)$ was found to be the predominant organism.

Jayarao and Henning (1999) examined bulk tank milk from 131 dairy herds in eastern South Dakota and western Minnesota for the presence of foodborne pathogens. Campylobacter jejuni, shiga-toxin producing Escherichia coli, Listeria monocytogenes, Salmonella spp., and Yersinia enterocolitica were detected in 9.2, 3.8, 4.6, 6.1, and $6.1 \%$ of bulk tank milk samples, respectively. $26.7 \%$ bulk tank milk samples contained one or more species of pathogenic bacteria. It was concluded that non A-grade raw milk producers were at a higher risk of having one or more pathogens in their bulk tank milk than were Grade A producers. 26.6\% dairy producers who consumed raw milk had one or more pathogenic bacteria in their bulk tank milk.

Donkar et al (2002) studied a total of 96 raw milk samples collected from the two sites in Ghana and identified Yersinia spp. (19.8\%), Klebsiella spp (16.7\%), Proteus spp. (7.3\%), Enterobacter spp. (6.3\%), Escherichia coli (2.1\%), and Staphylococcus spp (14.6\%), Bacillus spp. (11.5\%) and Mycobacterium spp. (1\%). Most of the organisms identified were enterobacteria and pathogenic indicating probable faecal contamination of the milk as a result of poor hygiene and though some of them occurred in few samples, the practice of 
pooling milk from different sources by traders, and the absence of pasteurization generally observed among them could increase the risk posed by such organisms.

Soomro et al., (2002) examined hundred raw milk samples. All the samples were inoculated on different bacteriological media and a number of biochemical tests were performed for the confirmation of the isolate. The results revealed that out of 100 milk samples $57 \%$ showed growth of E.coli. The highest number of milk samples contaminated with E. coli was recorded in milk samples obtained from milk vending shops and houses.

Esther et al (2003) evaluated raw and bottled commercial pasteurised milk from two processing plants in Gaborone, Botswana for mesophilic, psychrotrophic, proteolytic and lipolytic bacteria. Proteolytic-psychrotroph counts ranged between $10^{1}$ and $10^{5} \mathrm{CFU} / \mathrm{ml}$ in both milk types. Corynebacterium pseudodiphtheriticum (44\%) and Bacillus brevis $(72 \%)$ predominated in raw and commercial pasteurised milk respectively. Trypsin and chymotrypsin were detected in isolates of Bacillus circulans, Pseudomonas cichorii and Micrococcus lentus. Esterase and esterase lipase activity were observed in Corynebacterium nitrilophilus, Pseudomonas fragi, B. circulans, Bacillus coagulans, and $M$. lentus. The study demonstrated that postprocess contamination and ineffective pasteurisation compromised the quality and shelf life of pasteurised milk.

Oksuz et al., (2003) examined 100 raw milk samples from different bovines for the presence of E. coli O157. Some physical and chemical properties were investigated. According to the analysis results, E. coli O157 was determined in $1 \%$ of the total raw milk samples. Shabini (2003) microbiologically analyzed 40 samples of raw milk to evaluate the degree of environment pollution and its source examining the kinds and groups of contaminants. All the samples had high total count and were positive for coliforms. It shows a high rate of microbial environment pollution and the presence of fecal contamination in the area. Kessel et al., (2004) conducted a study to determine e prevalence of Salmonella, Listeria monocytogenes and fecal coliforms in bulk tank milk in the United States. 861 bulk tank milk samples were collected from farms in 21 states. $95 \%$ of the samples contained fecal coliforms. Salmonellae were isolated from $2.6 \%$ of the raw milk samples and $L$. monocytogenes was isolated from $6.5 \%$ of the samples.

Ekici et al., (2004) examined 36 samples of sheep milk, 25 samples of goat milk and 4 samples of cow milk. S. aureus was isolated from 12 samples while $E$. coli was isolated from 6 samples. Salmonella spp. could not be isolated in any of the samples.

Kivaria et al., (2006) examined 128 milk samples and the mean total bacterial count was $8.2 \times 10^{6} \mathrm{cfu} / \mathrm{ml}$, and major bacterial isolates from the milk samples were Escherichia coli (6.3\%), Bacillus cereus (6.3\%), Staphylococcus aureus (6.3\%) and Streptococcus agalactiae (6.3\%), Enterobacter aerogenes (5.6\%) and Enterococcus faecalis (4.7\%).

Chatterjee et al., (2006) conducted a study to assess the raw milk quality in Tarakeshwar Out of ten raw milk samples, the microbial colonies were found to be high in six samples and the colony content was low in rest four samples. The methylene blue test performed for raw milk samples showed that out of ten samples, the five samples were poor, two samples were fair, two samples were good and only one sample was found to be an excellent. 
Erica et al., (2007) reported that from 1988 to 2005, a total of 33 outbreaks of Campylobacter, Salmonella and E. coli O157:H7 infections associated with raw milk consumption had occurred. Escherichia coli, Mycobacterium bovis, Listeria monocytogenes and species of Campylobacter, Brucella and Salmonella are the most common contaminants of raw milk.

Schneider et al., (2008) reported that in California in the month of September, 2006 six children were admitted to hospital due to illness caused by consumption of raw milk. The milk was found to be contaminated with Escherichia coli O157:H7.

Nero et al., (2008) examined 210 raw milk samples collected from four important milk producing areas in Brazil for the presence of L. monocytogenes and Salmonella spp., and for enumeration of indicator microorganisms: mesophilic aerobes, total coliforms and Escherichia coli. The pathogens were not isolated in any raw milk sample, but poor microbiological quality was confirmed by the high levels of indicator microorganisms.

Altalhi and Hassan (2009) analyzed the bacterial quality and safety of raw milk sources in Taif region (Western Saudi Arabia) for the natural contamination of fecal coliform and Escherichia coli by standard most probable number method and recovered thirty-three E. coli strains from raw milk sample sources, which were contaminated by fecal coliform. Results suggested a possibility of potential public health threat of $E$. coli originating from raw milk sources.

Raw milk kept at refrigerator temperatures for several days invariably shows presence of several bacteria of the genera such as Bacillus, Enterococcus, Lactobacillus, Lactococcus, Leuconostoc, Microbacterium, Micrococcus, Propionibacterium, Proteus, Streptococcus, coliforms, and others
(Ledenbach and Marshall, 2009)

Montel et al., (2014) studied that microorganism multiply under the favourable conditions. The raw milk microbial population was numerous composed of spoilage, pathogenic micro organism with high technological significance. Similar results were observed by Perin et al., (2017).

Mohamed et al., (2017) analysed the microbial quality of raw milk involved count of aerobic mesophilic bacteria, total coliform, yeast and moulds, and common milk born pathogens namely Shig toxin producing Escherichia coli (STPC), Salmonella spp., Staphylococcus aureus, Streptococci, Brucella spp. and Mycobacteria.

The investigation of Owusu-Kwarteng et al (2018) showed that the prevalence of Listeria monocytogenes obtained in raw cow milk from the Northern regiont of Ghana was $8.8 \%$, whereas no L. monocytogenes was detected in boiled cow milk.

\section{Contamination in Pasteurized Milk}

Felsenfeld et al (1950) conducted a survey on pasteurized milk and found that pasteurized milk sold in the market was free from Salmonella.

Varela and Olarte (1952) examined 520 samples of Mexican certified milks and isolated 25 strains of salmonellae belonging to different serotypes.

Leoford et al., (1983) surveyed 80 commercially processed milk samples and found that $10 \%$ of the samples were positive for coliforms when tested within 24 hours of processing, $60 \%$ were positive after 10 days storage of samples at $6.7^{\circ} \mathrm{C}$ indicating that during storage the number of coliforms increases. 
Kapadnis and Panse (1986) examined 40 pasteurized milk and 20 raw milk samples collected from four dairies situated in Pune city. No Salmonella was isolated from pasteurized milk. Coliform count in raw milk ranged from 160 to $1100 / 100 \mathrm{ml}$ indicating faecal contamination but raw milk was not examined for Salmonella.

Lin et al., (1998) examined 232 milk samples and 122 environmental swabs collected from two dairy plants to determine the sources of Bacillus cereus in pasteurized milk and observed that incidence and average count of B. cereus spores in raw milk was very high and similar to those of $B$. cereus vegetative cells in pasteurized milk whereas in environmental swabs it was low suggesting that $B$. cereus spores in raw milk were the major source of B. cereus in pasteurized milk and that post-pasteurization contamination along the milk processing lines was possibly a minor source of B. cereus in pasteurized milk. Da Silva et al., (2001) examined 90 samples of pasteurized milk of three different commercial brands in Brazil and found that bacterial counts were above the regulated values of the Brazilian government. Among 208 strains of $E$. coli isolated, $46(22.1 \%)$ were entero pathogenic E.coli (EPEC). Isolation of EPEC from pasteurized milk gives an indication of the presence of other enteropathogens.

Khan and Malik (2002) examined 36 samples of raw and pasteurized milk for total viable count, staphylococcal count, total coliforms, faecal coliforms, Salmonella and Shigella. Total viable count in raw and pasteurized milk was found to be in the range of $15,900 \mathrm{x}$ $10^{6}$ to $2,59,000 \times 10^{6}$ and $154 \times 10^{6}$ to 24000 x $10^{6} \mathrm{cfu} / 100 \mathrm{ml}$, respectively. The mean staphylococcal count in raw milk was $470 \mathrm{x}$ $10^{6} \mathrm{cfu} / 100 \mathrm{ml}$. Total coliforms were $2.4 \mathrm{x}$ $10^{3} \mathrm{MPN} / 100 \mathrm{ml}$ in raw milk and $2.13 \times 10^{3}$ MPN/100 $\mathrm{ml}$ in pasteurized. Faecal coliforms in all the samples of raw milk and pasteurized milk were found to be $1.9 \times 10^{3}$ and, $1.5 \times 10^{3}$ MPN/100 ml respectively. Salmonella and Shigella were not detected in any of the milk samples.

lgumbor and Milngo (2002) conducted a study to assess the bacteriological quality of pasteurized milk and ice cream sold in Harare, using the direct plate count method and the methylene blue dye reduction test The results from the direct plate counts revealed the presence of both pathogens and non pathogens. Bacillus spp., coagulase Staphylococcus spp., Micrococcus spp., Streptococcus spp., Diphtheroids, Fusiform bacteria, Klebsiella spp. and Citrobacter spp were isolated from both the type of samples. No significant differences were found in the plate counts of the samples obtained from the depots and the outlets for the milk and ice cream samples.

O'Ferrall-Berndt (2003) evaluated pasteurized milk available to the consumer from milk shops in a pre-defined area of Pretoria compared with a national distributor's milk. Of the 135 milk samples purchased from milk-shops, $87 \%$ were not fit for human consumption whereas the national distributor's milk did not contain any pathogens. $38.5 \%$ of samples from milk shops were alkaline phosphatase positive, indicating probable inadequate pasteurisation. Total aerobic plate and coliform counts were generally high for all milk-shop milk samples.

Escherichia coli were detected in $1 \mathrm{ml}$ of $17 \%$ of milk-shop milk, $95 \%$ of which originated from milk which was alkaline phosphatase positive. Staphylococcus aureus was isolated from $40 \%$ of milk-shop milk samples, and $S$. aureus enterotoxins from $7.8 \%$ of 51 cultures. It was concluded that milk from milk shops was unsafe and poses a serious public health risk to consumers. 
Chatterjee et al., (2006) conducted a study to assess pasteurized milk samples. The colony count was low in seven samples and high in three samples. Out of ten pasteurized samples, nine samples were of good quality and one was found to be excellent. Dr Malka Halpern from the University of Haifa, Israel (2008) has identified a new bacterium Chryseobacterium oranimense, which can grow at cold temperatures and secretes enzymes that have the potential to spoil milk.

Ali Ahmed (2009) isolated 14 strains of Salmonella out of 169 samples of milk products e.g. cream, dahi, cheese, khoya and khoya products collected from various dealers in Bareilly city. The presence of Salmonella was probably due to poor hygienic practices and such contamination of milk products is of great public health significance.

Baylis (2009) studied cytotoxigenic E.coli sero-groups may infect humans through consumption of infected raw unpasteurized milk and milk products, which have significant contribution to the reported cases of Shiga toxin producing E. coli (STEC) in humans. Martin et al (2012) examined pasteurization of milk at lower temperature $\left(76.1^{0} \mathrm{C}\right.$ vs $\left.79.4^{0} \mathrm{C}\right)$ induced significantly lower bacterial count (log $\mathrm{cfu} \mathrm{mL}$ in pasteurized milk (1.39 vs 1.58) which remained lower (3.74 vs 4.82) even after 21 days post processing storage at $6^{0} \mathrm{C}$ due to lactoperoxidase system.

Ivy et al (2012) observed that spore forming bacteria can survive pasteurization in spore form, several aerobic spore formers that can grow under refrigeration conditions have been identified in both raw milk and HTSTpasteurized fluid milk.

Harvert et al., (2016) studied that noncoliform Enterobacteriaceae are an important group of bacteria including organism such as Proteus which are less frequent contaminants in pasteurized fluid milk.

\section{Contamination of Milk Products}

Patel et al., (1962) isolated S. enteritidis from Basudi, a milk product like khoya following a food poisoning outbreak in Gujurat. Moutsy and Nasr (1964) examined 40 samples of Kareish cheese (An Arabian product) bacteriologically and found that the cheese contained 68 million to 6.3 billion bacteria per gram and they could isolate $S$. typhimurium only from one sample.

Garg and Mandokhot (1984) surveyed urban and rural areas to study the attitude of the makers and handlers of sweet-meat towards the hygiene sweet preparation and found that the respondents of urban areas are having more positive attitude towards hygienic sweet preparation than the respondents of rural areas. The study also revealed that Escherichia coli. is a potential pathogen isolated from milk products suspected to be associated with the outbreaks of gastroenteritis and food poisoning in human being.

Al-Rajab et al., (1986) demonstrated Salmonella in 32 (8\%) out of 400 samples of locally produced milk products in Iraq. Icecream (10.9\%), Kishfa (10\%), Gaymer $(7.5 \%)$, cheese $(6.6 \%)$ and Yoghurt $(1.6 \%)$ were found positive for salmonellae. The bacteriological examination of ice-cream in Netherlands. None of 36 samples of ice-cream selected out of 351 was found to contain salmonellae and the isolation of two percent of salmonellae out of 360 samples of different frozen dairy products collected from Bangalore city.

Ratnam and March (1986) reported a major outbreak of gastroenteristis in Canada due to consumption of cheddar cheese contaminated with Salmonella. Samples from the interior of cheese blocks yielded salmonella more 
frequently as compared to the samples from exterior. The number of Salmonella from factory -sealed blocks of cheese and in samples obtained from homes of known cases of salmonellosis ranged from 3 to 9 per $100 \mathrm{~g}$ cheese.

Singh et al., (1994) examined 110 samples comprising raw milk, raw cream and burfi collected from different hostels and residences of Pantnagar Campus for their sanitary quality by determining standard plate, coliform and psychrophilic counts. It was observed that 37.72 percent samples of milk and 73.33 percent of cream were of poor quality and 84.0 percent samples of burfi were unsatisfactory. The mean coliform $\log 10$ counts in raw milk and cream were recorded as $4.477 / \mathrm{ml}$ and $4.740 / \mathrm{g}$ respectively indicating the possibility of fecal contamination.

The Journal of the American Medical Association (JAMA) (1999) reported the source of a particular Salmonella typhimurium DT104 infection of Hispanics in the Northern California and Yakima, Washington (United States) areas was due to unpasteurized queso fresco. California allows producers to sell unpasteurized milk and milk products.

Araujo et al., (2001) analyzed different types of cheese samples from Salvador City in Bahia, Brazil and found that Minas frescal cheese was of low quality due to the contamination of coliform bacteria, which included Staphylococcus epidermidis, Proteus rettgeri, Escherichia coli, Enterobacter aerogenes, Enterobacter and Micrococcus spp.

Ikram et al., (2001) examined 50 samples of packed and unpacked butter for total viable count, mould and yeast count, spore formers and coliform and found that the microbial load in the unpacked sample of butter was highest i.e., $3.8 \times 10^{6} / \mathrm{gm}-6.6 \times 10^{6} / \mathrm{gm}$. The coliform count was found maximum in unpacked sample and one of the packed sample of butter (Kausar brand) i.e., 39/ml. The unpacked sample of butter contained highest number of aerobic spore formers i.e., 280/gm. The anaerobic spore-formers were found absent in 20 samples of butter and the rest contained in the range of $0-170 / \mathrm{gm}$.

Soomro et al., (2002) examined sixty milk product samples namely Gulabjamun, Mawa and Dahi. These samples were randomly collected from different localities/sources of Tandojam. All the samples were inoculated on different bacteriological media and a number of biochemical tests were performed for the confirmation of the isolate. Among the 60 milk product samples $31(51.66 \%)$ showed growth of E.coli, the highest rate of contamination was found in Mawa/Khoa samples.

Simeao et al., (2002) investigated the cause of food poisoning outbreaks In February and May of 1999, the sanitary services of the Health Board in the cities of Manhuaçu and PassaQuatro, Minas Gerais, Brazil, involving a total of 378 individuals. Samples of the cheese and raw milk were collected and analyzed. The results showed the presence of Staphylococcus aureus and production of enterotoxins SEC and SED.

Oksuz et al., (2003) examined 50 white pickled cheeses manufactured from raw milk for the presence of E. coli $\mathrm{O} 157$ and investigated physical and chemical properties. E. coli $\mathrm{O} 157$ was determined in $4 \%$ of the cheese samples. $\mathrm{pH}$ values were found to be higher than 4.50 in $80 \%$ of the total cheese samples. It was due to not using lactic starters in cheese manufacturing process. Due to the low acidity of the cheese samples, E. coli O157 counts may increase and its survival time may be longer than in cheeses made 
using starter cultures. Thus, it was concluded that white pickled cheeses manufactured from unpasteurized milk have a potential infection risk as a result of $E$. coli $\mathrm{O} 157$ existence.

Ojokoh A.O. (2006) carried out studies on the microbiological quality of ice cream obtained from vendors in Akure. The samples were screened for total viable counts which ranged $1.8 \times 10 \mathrm{cfu} / \mathrm{g}-2.0 \times 10 \mathrm{cfu} / \mathrm{g}$. Seven bacterial and three mould isolates were obtained. Staphylococcus species, Klebsiella species and Aspergillus species recorded maximum percentage occurrence of $100 \%$ while the least value of $10 \%$ occurrence was for Streptococcus species isolated from sample.

Preeti Bhatnagar et al., (2007) conducted a study to determine bacterial contaminants in Khoa samples sold in Gwalior and Morena city in Madhya Pradesh. Total Fifty samples of Khoa were cultured on several media and bacterial colony counts were made. Predominant organisms isolated were Staphylococcus and Streptococcus species. It was concluded that contamination of khoa by pathogenic bacteria could be an important factor of gastrointestinal illness in the consumers.

Jayant et al., (2007) examined eighteen peda samples procured from A and B grade retail shops for their overall microbiological quality and for the presence of foodborne pathogens viz. Staphylococcus aureus, Salmonella sp., Coliforms, Listeria monocytogenes, Yersinia enterocolitica and Bacillus cereus. The microbiological quality of peda samples from B grade shops was very poor as compared to peda from A grade shop. These showed very high total bacterial counts $\left(6 \times 10^{7} \mathrm{cfu} / \mathrm{g}\right)$, high counts of $S$. aureus (as high as $7 \times 10^{6}$ $\mathrm{cfu} / \mathrm{g}$ ) and presence of coliforms and Listeria and Yersinia sp. in $33 \%$ of the samples. All the samples from a grade shops were also positive for $S$. aureus though negative for coliforms, Yersinia, Salmonella, Listeria and B. cereus. Gamma irradiation of peda reduced overall bacterial load and $S$. aureus and coliforms could be totally eliminated.

\section{Contamination from Handlers}

Garg and Mittal (1991) reported that Enterococci are widely distributed in nature and gain entry into milk and milk products through the water supply, equipment, and insanitary and unhygienic conditions of production and handling. The prolific growth of enterococci in foods may lead to formation of clinically significant levels of pressor amines that are very thermostable and therefore remain active even after heat processing. These pressor amines may be involved in the onset of migraine attacks and produce hypersensitive crises in psychiatric patients who are being treated with monoamine oxidase inhibitors for depression. Saran (1995) reported that raw milk quality can be directly related to bacterial content of the milk. Milk with low bacterial and somatic cell counts cannot be produced unless milking equipment is effectively cleaned and disinfected between milking and the cows are kept healthy. Giffel and Beumer (1998) conducted a research on dairy farms, at two dairy processing plants and pasteurized milk to determine the major contamination sources of milk with Bacillus cereus. On dairy farms it was found that udders get contaminated from soil and feces, finally resulting in the presence of $B$. cereus in raw milk. The organism could be detected in $35 \%$ of the raw milk samples analyzed. During processing, an increase in the percentage of positive samples was observed suggesting equipment may also play an important role in contamination.

Birgitta et al., (2000) studied the involvement of a pasteurizer in the contamination of milk by Bacillus cereus in a commercial dairy 
plant. Dogan and Boor (2004) studied that high total bacterial number in bulk tank milk may be due to an environmental pathogen Streptococcus uberis which may be added to the milk due to bovine mastitis. It does not grow during storage of raw milk at $<10^{\circ} \mathrm{C}$ temperature (storage temperature of raw milk according to PMO standards FDA 2001).

Jayarao et al., (2004) studied the relationship between different bacterial groups that occur in bulk tank milk by collecting samples from one hundred twenty six dairy farms of Pennsylvania. The samples were examined for somatic cell count(SCC), preliminary incubation count, laboratory pasteurization count, coagulase-negative staphylococcal count, environmental streptococcal count, coliform count, and gram-negative noncoliform count. The milk samples were also examined for presence of Staphylococcus aureus, Streptococcus agalactiae, and Mycoplasma. It was observed that there is a positive relationship between SCC and other parameters but coliform count was less related to somatic cell or other bacterial count.

Oliver et al., (2005) studied the presence of food borne pathogens in milk and the dairy farm environment. They studied how the presence of pathogens depends on ingestion of contaminated feed followed by amplification in bovine hosts and fecal dissemination in the farm environment. The final outcome of this cycle is a constantly maintained reservoir of food borne pathogens that can reach humans by direct contact, ingestion of raw contaminated milk or cheese, or contamination during the processing of milk products. Srairi et al., (2006) carried out a research to evaluate the hygienic quality of raw milk and its relationship to milking conditions in Morocco. They examined 109 bulk milk samples obtained directly after milking from 109 different farms for their hygienic quality. The raw milk tested was found to be of poor hygienic quality. three types of milking profile were studied.

Profile 1: one milking per day, calf suckling and irregular cleaning of hands and udder;

Profile 2: one to two milking per day, calf suckling and regular hands and udder cleaning.

Profile 3: two milking per day, no calf suckling and regular cleaning of hands and udder. It was concluded that calf suckling practice may play a role in reducing the fæcal coliforms and staphylococci counts in milk by the elimination of the foremilk, which is known to be the most contaminated by bacteria, whereas cleaning practices, under the current hygienic conditions in the farms, seem to be ineffective to generate good hygienic environment. Ali Ahmed Hassabo (2009) investigated the adulteration of marketable fresh milk adulterated with water and starch at Khartoum state. Three hundred samples from Khartoum, Omdurman and Bahri were collected. All samples were chemically examined and analyzed to observe their quality. The research concluded that the adulteration at Khartoum state is due to addition of water $(35.3 \%)$ rather than Starch.

Olaimat et al., (2018) reviewed on the emergence of antibiotic resistance among L.monocytogenes strains isolated from food products and possible ways the resistance has developed. Due to this emergence of antibiotic resistance of the pathogen, future outbreaks and spread of the diseases may be hard to manage.

\section{References}

Adesiyun, 1994. Bacteriological quality and associated public health risk of preprocessed bovine milk in Trinidad. Int 
J Food Microbiol.; 21(3):253-61

Ali Ahmad Hassabo Adam, 2009. Milk Adulteration by Adding Water and Starch at Khartoum State. Pakistan Journal of Nutrition 8 (4): 439-440.

Altalhi Abdullah D. and Hassan Sabry A., 2009. Bacterial quality of raw milk investigated by Escherichia coli and isolates analysis for specific virulencegene markers. Doi:10 .1016/j.foodcont 2009.01.005.

C.J. Harvert, A. Alles, N. Martin, K. Boor, M. Wiedmann, 2016. Evaluation of different methods to detect microbial hygiene indicators relevant in the dairy industry. J. Dairy Sci., 99;7033-7042.

Chatterjee, S.N., I. Bhattacharjee, S.K. Chatterjee and G. Chandra, 2006. Microbiological examination of milk in Tarakeswar, India with special reference to coliforms. Afr. J. Biotech., 5: 13831385.

da Silva, Z.N. , Adriana S da Cunha, Angela $\mathrm{C}$ de F Almeida and Mara LP Queiroz, 2001. Isolation and serological identification of enteropathogenic Escherichia coli in pasteurized milk in Brazil. Rev. Saude Publical. 35 no. 4 Sao Paulo.

Das R. and Nag N. C., 1986. Examination of market milk collected from Calcutta and neighbouring places with special reference to Salmonella. Indian J. Anim. Hlth.25: 145149.

Desmasures N, Bazin F, Guéguen M., 1997. Microbiological composition of raw milk from selected farms in the Camembert region of Normandy. J Appl Microbiol. Jul;83(1):53-8.

Erica Weir, Joanne Mitchell, Steven Reballato and Dominic Fortuna, 2007. Raw milk and the protection of public health. CMAJ•177 (7) doi:10.1503/cmaj.071035 CMAJ • September 25, 2007; 177 (7).

Ekici, K., H. Bozkurt and O. Isleyici, 2004. Isolation of Some Pathogens from Raw
Milk of Different Milch Animals. Pakistan Journal of Nutrition 3 (3): 161162

ES Donkor, KG Aning, and J Quaye, 2007. Bacterial Contaminations of Informally Marketed Raw Milk in Ghana Ghana Med J. June; 41(2): 58-61.

Esther N. Aaku, Ernest K. Collison, Berhanu A. Gashe and Sisai Mpuchane, 2004. Microbiological quality of milk from two processing plants in Gaborone Botswana . Food Control Volume 15, Issue 3, Pages 181-186.

Galbraith N S, Forbes P, and Clifford C.,1982. Communicable disease associated with milk and dairy products in England and Wales 1951-80. Br Med J (Clin Res Ed).; 284(6331): 1761-1765.

Garg D. N., Bhargava D. N. and Narayana K. G., 1977. Pathogenic bacterial flora of raw market milk. Indian J. Dairy Sci. 30: 3639.

Garg, S.R. and Mandokhot U.V., 1984. Microbiological quality of pedha. $J$. Food. Sci. Technol, 20:170.

Giffel MC \& Beumer RR., 1998. Isolation, identification and characterization of Bacillus cereus in the dairy industry: 123(21):628-32.

Grade "A" Pasteurized milk Ordinance, 2005 Revision. U.S. Department of Health \& Human Service, Public Health Service, Food andDrug Administration.

Humphrey T.J. , Hart R.J.C., 1988. Campylobacter and salmonella contamination of unpasteurized cows' milk on sale to the public. DOI 10.1111/j.1365-2672.

Igumbor E. O., Obi C. L., Tendai Milngo, 2002. Bacteriological examination of pasteurized milk and milk products sold in Harare, Zimbabw Journal of food science and technology ISSN 0022-1155.

Ikram-ul-Haq, Nuzhat Inarm, Sikander AN and M.A.Qadeer, 2001. Incidence of Coliform in Butter. On Line Journal of 
Biological Sciences 4 (3): 175-1 77.

Jayant Bandekar, Anu Kamat and Paul Thomas., 2007. Microbiological quality of the dairy product pedha and its improvement using gamma radiations. Journal of Food Safety Volume 18 Issue 3, Pages $221-230$.

Jayarao, B.M. and Henning D.R., 1999. Prevalence of foodborne pathogens in bulk tank milk. J. Dairy Sci., 81:21572162.Curr.Res. Bacterio!., 1 (2): 56-63, 2008.

Jayarao, B.M., Piplat S.R., Sawant A.A., Wolfgang D.R. and Hedge N.V., 2004. Guidelines for monitoring bulk tank milk somatic cell and bacterial counts. J. Dairy Sci., 87: 3561-3573.

Kala Robert, Samkova Eva, Pecova Lenka, Hanus Oto, Sekmokas Kestutis and Riaukiene Dalia., (2018). An Overview of Determination of Milk Fat: Development, Quality control Measures and Application. Acta Universitatis Agriculture et Silviculture Mendelianae Brunensis, 66(4):1055-1064.

Kapadnis B. P. and Panse M. V., 1986. Bacteriological quality of pasteurized milk from Poona city. Indian J. Microbiol. 26 : 294-296.

Khalilur Rahman Khan M. and Malik Abdul, 2002. Microbiological quality of milk. Journal of food science and technology ISSN 0022-1155.

L. Simeao do Carmo, R. Souza Dias, V. Roberto Linardi, M. Jose de Sena, D. Aparecida dos Santo, 2002. Food poisoning due to enterotoxigenic strains of Staphylococcus present in Minas cheese and raw milk in Brazil. Food Microbiology, Volume 19, Issue 1.

Leoford R.A., Senyk G.P., Kotsides E. and Wolff E.T., 1983. Prelimnary incubation methods for detection of coliforms in commercially processed milk samples. Journal of Dairy Sc. Vol.66. No.8

Lin S, Schraft H, Odumeru JA, Griffiths
MW., 1998. Identification of contamination sources of Bacillus cereus in pasteurized milk. Int $J$ Food Microbiol.;43(3):159-71.

Martin, H.C. den Bakker, B.M. Xavier, M. Wiedmann, K.J. Boor. Identification and characterization of psychrotolerant sporeformers associated with fluid milk production and processing, 2012. Appl. Environ. Microbiol., 78:1853-1864.

Matta H., Punj V., 1999. Isolation and identification of lipolytic, psychrotrophic spore forming bacteria from raw milk. International journal of dairy technology ISSN 1364-27X ; vol. 52, no.2, pp. 59.

McManus, C., and Lanier J. M., 1987. Salmonella, Campylobacter jejuni, and Yersinia enterocolitica in raw milk. J. Food Prot. 50:51.

Montel, M.-C., Buchin, S., Mallet, A., Delbes-paus, C., Vuitton, D.A., Desmasures, N., et al., 2014. Traditional cheeses: rich and diverse microbiota with associated benefits. Int. J. Food Microbial. 177 ; 136-154.

Nero L. A., de Mattos M. R, de Aguiar Ferreira Barros M., Ortolani M. B. T., Beloti V. and de Melo Franco B. D. G., 2008. Listeria monocytogenes and Salmonella spp. in Raw Milk Produced in Brazil: Occurrence Indigenous Microbiota in Volume 55 Issue6 Pages 299-305.

O'Farrell - Berndt MM., 2003. A comparison of selected public health criteria in milk from milk-shops and from a national distributor. J S Afr Vet Assoc.; 74(2):3540.

Oksuz, O., M. Arici, S. Kurultay and T. Gumus, 2003. Incidence oí Escherichia coli 157 in raw milk and white pickled cheese manufactured from raw milk in Turkey. Food Control, 15: 453-456.

Oliver S.P., Jayarao B.M., Almeida R.A., 2005. Foodborne pathogens in milk and the dairy farm environment: food safety and public health implications. Foodborne 
Pathog Dis. 2005 Summer;2(2):115-2.

Ombui J. N., Kaburia H. F. A., Macharia J. K. ,Nduhiu G., 1994. Coliform counts and Escherichia coli in raw commercial milk from dairy farmers medical journal vol. 71, no.10, pp. 635-639

Patel T.B., Bomen T.J.and Thokore V.H., 1962. An outbreak of Salmonella food poisoning in Mehmadabad Town (Gujurat). Indian J. Med. Sci. 16: 864866.

Perin, L.M., Sardaro, M.L.S., Nero, L.A., Neviani, E., Gatti, M., 2017. Bacterial ecology of artisanal Minas cheeses assessed by culture-dependent and independent methods. Food Microbial. 65; 160-169.

Preeti Bhatnagar, Abdul Arif Khan, Manisha Jain, Shuchi Kaushik and Sudhir K. Jain, 2007. Microbiological study of khoa sold in Chambal region.

Saran A.,1995. Disinfection in the dairy parlour. Rev Sci Tech. 1995 Mar; 14(1):207-24.

Satyendra K., Garg and Brij K. Mital, 1991. Enterococci in Milk and Milk Products. Vol. 18, No. 1, Pages 15-45

Schneider J, Mohle-Boetani J, Vugia D, Menon M, 2008. Escherichia coli 0157:H7 Infections in Children Associated With Raw Milk and Raw Colostrum From Cows.

Shabini L., 2003. Microbial pollution of milk by environment as an indicator of contamination rate. Journal of Environmental Protection and Ecology 4, No 2, 401-405

Singh Y, Kumar A \& Sharma VD, 1994. Sanitary analyses of milk, cream and burfi. Indian Journal of Comparative Microbiology Immunology and Infectious Diseases. 15 (1 and 2): 12-4.

Soomro A.H., Arain M.A., Khaskheli M. and Bhutto B., 2002. Isolation of E. coli from raw milk and milk products in relation to public health sold under market conditions at Tandojam. Pak $J$ of Nutrition 1, 151152.

Soomro A.H., Arain M.A., Khaskheli M. and Bhutto B., 2002. Isolation of Staphylococcus aureus from milk products sold at sweet meat shops of Hyderabad. OnLine Journal of Biological Sciences 3 (1): 91-94.

Soomro, A.H., M.A. Arain, M. Khaskheli and B. Bhutto, 2002. Singh Y, Kumar A \& Sharma VD, 1994. Sanitary analyses of milk, cream and burfi. Indian Journal of Comparative Microbiology Immunology and Infectious Diseases. 15(1 and 2): 124.

Srairi M T, Moudnib J, Rahho L and Hamama A., 2006. How do milking conditions affect the hygienic quality of raw milk? Case study from Morocco dairy farms. Livestock Research for Rural Development 18(7).

Svensson, Eneroth ,Johanne Brendehaug ,Goran Molin and Anders Christansson, 2000. Involvement of a pasteurizer in the contamination of milk by Bacillus cereus in a commercial dairy plant Journal of Dairy Research 67: 455-460 Cambridge University Press.

Taylor DN, Bied JM, Munro JS, Feldman RA., 1982. Salmonella dublin infections in the United States, 1979-1980. J Infect Dis; 146:322-7.

Van Kessel, J.A., J.S. Karns, L. Gorski, B.J. McCluskey, and M.L. Perdue, 2004. Prevalence of Salmonellae, Listeria monocytogenes and fecal coliforms in bulk tank milk on U.S. dairies. J. Dairy Sci. 87:2822-2830.

Vasavada, P.C., 1988. Pathogenic bacteria in milk -A review. J. Dairy Sci., 71: 28092816.

Wood D. S. Collins-Thompson D. L. Irvine D. M. and Myhr A. N., 1984. Sources and persistence of Salmonella muenster in naturally contaminated cheddar cheese. $J$. Food Prot. 47:20-22. 


\section{How to cite this article:}

Harleen Kaur Talwar and Anshu Sibbal Chatli. 2020. A Critical Review on Quality Testing of Milk and Milk Products. Int.J.Curr.Microbiol.App.Sci. 9(08): 1068-1081.

doi: https://doi.org/10.20546/ijcmas.2020.908.117 